\title{
COMPLIANCE AUDITING IN PUBLIC ADMINISTRATION: UKRAINIAN PERSPECTIVES
}

\author{
Yuliia Slobodianyk', Svitlana Shymon ${ }^{2}$, Volodymyr Adam ${ }^{3}$
}

\begin{abstract}
Purpose. In December 2016, the updated INTOSAI standards for government auditing were enacted that provided a methodological basis for conducting various forms of public audit, in particular, public compliance auditing. The use of ISSAIs is aimed at maintaining high-quality control measures to ensure the public administration system accountability and transparency. The aim of the research is to consider the current state and prospects of introducing the public compliance auditing into the practice of the Supreme Audit Institution in Ukraine. Design/ methodology/approach. The methodological basis of the study was to conduct the best practices comparative analysis in public auditing and to implement the desktop study of theoretical scientific researches, open analytical data produced by governmental and non-governmental bodies. Findings. The analysis of the Accounting Chamber of Ukraine's reports proved that the control activities contained the compliance auditing elements. In this context, a proper legal framework for carrying out compliance auditing is not yet established and the appropriate methodological developments are not available. The author believes that implementing the ISSAI standards for the public compliance auditing may be accelerated due to the step-by-step implementation of the activities proposed. Practical implications. The specific recommendations on implementing the compliance auditing in accordance with the ISSAI standards requirements are important to regulators. Originality/value. The study can be the basis for further research in the field of the public compliance auditing theory and methodology, and the results may be useful for practitioners.
\end{abstract}

Key words: compliance auditing, regularity, propriety, transparency, public administration.

JEL Classification: K20, P43

\section{Introduction}

Over the last years, the role of Supreme Audit Institutions (SAIs) in supporting the good governance in the public sector has been reconsidering. General Assembly of the UN in the Resolutions 2011 (A/RES/66/209) and 2014 (A/RES/69/228) noted the critical role of SAIs in supporting the efficient, accountable, effective and transparent public administration that forms the basis for achieving the Millennium Development Goals and the Sustainable Development Goals (A/RES/70/1).

The activities of the International Organization of Supreme Audit Institutions (INTOSAI), which consists today of 194 full members and 5 associated members, are directed to high standards of external independent audit support, sharing of the best practices in ensuring the efficient work of governments, their transparency, accountability, and effectiveness in the fight against corruption. At the last XXII INTOSAI Congress, which was held in the United Arab Emirates in December 2016, The Abu Dhabi
Declaration was adopted. The important issues that were discussed at the Congress included the adoption of an INTOSAI Strategic plan for 2017-2022 and the revised version of individual ISSAI's professional standards.

Now the current ISSAI standards secured three main forms of public audit - financial auditing, performance auditing, and compliance auditing. While the financial auditing and performance auditing have long been included in the SAIs' activities of different countries, this is not true for the compliance auditing.

Nowadays many countries, particularly Bulgaria, Denmark, Estonia, Finland, Germany, Hungary, Ireland, Latvia, Slovenia and the like conduct public compliance auditing. The positive experience of these countries in conducting the compliance auditing contributed to its generalization in the writing of ISSAI standards, which allows extending it to other countries. At the same time, different types of SAIs, particularities of legislation and government control systems will influence the process of public compliance auditing.

\footnotetext{
Corresponding author:

${ }^{1}$ Kyiv National Economic University named after Vadym Hetman, Ukraine.

E-mail: yslobodyanik@ukr.net

${ }^{2}$ Kyiv National Economic University named after Vadym Hetman, Ukraine.

${ }^{3}$ Lviv State University of Internal Affairs, Ukraine.

E-mail: volodymyr.adam@gmail.com
} 
Ukraine is in the process of reforming the public finance control system. The Accounting Chamber of Ukraine as the Supreme Audit Institution, was formed in 1996, is a member of INTOSAI since 1998 and EUROSAI - since 1999. In 2015, the Law of Ukraine "On the Accounting Chamber" renewal took place, which established the requirement of applying the ISSAI international standards. Without dwelling on the advantages and disadvantages of the law adopted, which require a special study, we note that in the list of the Accounting Chamber's powers the financial auditing and performance auditing are specified, but not the compliance auditing (Law of Ukraine On the Accounting Chamber 2015. s.4 (2)).

This non-compliance with ISSAI standards requirements resulted in investigating the prospects of the ISSAI standards in Ukraine in general and compliance auditing in particular. The logical structure of the research includes the consideration of the reasons for the emergence and development of the public compliance auditing as one of the main forms of the public audit, study of international best practice in this area, and the requirements of relevant ISSAI standards to assess the possibility of their use in the Ukrainian practice, analysis of the current situation, prospects of compliance auditing implementation in Ukraine, and identifying the recommendations for this process acceleration.

Methodological basis of the research presented was to conduct a comparative analysis of best practices in public auditing and desktop study of the documents of the UN, INTOSAI, the Verkhovna Rada of Ukraine, the Accounting Chamber of Ukraine, theoretical scientific researches and open analytical data produced by governmental and non-governmental bodies.

\section{Compliance auditing in the public sector: literature review and prerequisites for securing the compliance audit in the ISSAIs}

The compliance auditing refers to the traditional forms of an audit that next to financial auditing has been known since Ancient Egypt and China. As Dye and Stapenhurst (1998) noted, in the public sector in Europe the compliance auditing took on importance since the 18th century when the law compliance realization covered the financial accounts. At that time, the issues of public money receipt, saving and creation were of key importance (Othman et al., 2013). The public audit took a new value - to raise awareness as to public finances administration and management. The conception of state auditors independence and selfdependence was firmly established, the consolidation of legal provisions in public finances auditing was founded, and the basic institutional patterns of the public auditing were grounded, namely auditing chambers headed by the Auditor General (Anglo-Saxon tradition spread in
Great Britain, Denmark, Sweden, Finland and etc.) and judicial boards (French or Latin tradition widespread in France, Belgium, Spain, Italy etc.).

After World War II, there was a remarkable public audit expansion, new Supreme Audit Institutions were formed whose self-sufficiency and independence were assured by the Constitution of the country. The circle of bodies under control including not only the government institutions and enterprises but also private persons was widened. New methodologies of state earnings and losses auditing were created; the auditing was applied to not only the analysis of accounting legitimacy and accuracy and financial reporting reliability but to estimating the effective handling of public funds as well. International organizations uniting the supreme bodies of public finances control of different countries were established (INTOSAI, EUROSAI etc.).

The appearance of New Public Management in 1980th provoked the approaches changing in public sector accounting and auditing (Hood, 1995; ReichbornKjennerud, 2013). For example, Mintzberg (1980), while describing different types of organizational structures, notes that many public institutions have a simple and sound organizational structure which he classifies as the Machine Bureaucracy. Organizations that have such a structure are characterized by hierarchy and simple processes and operations, which repeat themselves, have the standardized form and are predictable. Therefore, external control in such organizations is associated with determining compliance with regulations, standards, and procedures. That is why the Machine Bureaucracy is associated with external compliance auditing (Mintzberg, 1980, p. 333). However, more complex organizational structures require different approaches in the field of control to assess not only compliance with regulated standards but also to determine their appropriateness, effectiveness, and efficiency.

The added complexity of organizational structures and management development contributed to a significant spread of the performance auditing that has been used successfully by countries such as Canada and Sweden since the late 50s of the 20th century. SAIs began to conduct inspections of public expenditures not only in respect of their compliance with the law but also in the context of social benefit.

At the end of the millennium, a number of scientific studies appeared in the field of public audit transformation in the direction of the performance audit development and its comparison with traditional forms of public audit, in particular with the compliance auditing (Funnell, 1994; Barzelay, 1997; Dye and Stapenhurst, 1998; Pollit et al., 1999; Jones and Pendlebury, 2000; Gomes, 2001 and others). Studies from Canada, Sweden, UK, USA spread in Europe, Australia, New Zealand, Asia, and South Africa. Researchers have noted the need to develop an appropriate methodology 
of assessing the performance, which should include an assessment of the economy, efficiency and effectiveness, develop the evaluation criteria, auditing techniques, consider fundamental weaknesses in the public audit function (Bowerman et al., 2003; Pearson, 2014).

At the same time, it should be noted that the compliance auditing does not become irrelevant and acquires further development, and the scientists such as Barzelay (1997), Pollit et al. (1999), Gomes (2001), Ruffner and Sevilla (2004), Mayne (2006) emphasize the necessity and importance of its conducting. Also, the compliance auditing continues to be instrumental in SAIs endowed with their own jurisdiction, to support decisions with relevant evidence (ReichbornKjennerud, 2013).

Gomes (2001) emphasizes the effectiveness of compliance auditing to evaluate the internal performance of the organization and its goal achieving. This idea was widely applied in practice, especially with the development of the institute of internal audit. In addition, adopted in the United States in 2002 the Sarbanes-Oxley Act and similar laws in other countries increased the development of internal control systems in organizations (Hua-Wei, 2009) and has become a powerful impetus to research in this area (Lenz and Hahn, 2015). This legislation had an effect both on the private sector and public institutions and organizations. Today, the internal compliance auditing in the public sector is aimed at the anti-money laundering procedures and financing of terrorism prevention, conflicts of interests, developing the policies and procedures aimed at the compliance of the organization's activities with current legislation, information flows protection, fraud and corruption control, etc.

In addition, the international standards, approved by The Institute of Internal Auditors (IIA) and Committee of Sponsoring Organizations of the Treadway Commission (COSO), contribute to further interrelation and development of internal and external public compliance audit, and securing the public compliance auditing in the ISSAIs confirms its importance and causes the necessity to make further investigations in the area.

Despite the long developmental history, in the last 200 years, the conception of the compliance auditing has not changed substantially. Thus, O'Regan (2004) defines compliance auditing as follows: "compliance audit - an audit of compliance with external regulations or internal control procedures". However, he emphasises that "... the verification of compliance with external or internal requirements..." is the primary goal of the compliance auditing (O’Regan, 2004, p. 70). Arens et al. (2012, p. 14) offer the similar definition: "A compliance audit is conducted to determine whether the auditee is following specific procedures, rules, or regulations set by some higher authority". The authors also point out that governmental units due to substantial regulatory control require the compliance audit conducting.
It should also be noted that in the international practice, the public compliance auditing is performed both by that name and as the "regularity audit". In some countries, such as in the Federal Republic of Germany, these names are used in parallel. Along with this, different SAIs perceived the essence of the public compliance auditing as virtually the same and cover their contents on their own public resources, in particular:

"... The essence of "Compliance Audit" is in assessing the extent to which laws and regulations (authorities) have been respected" (Supreme Audit Institution of India, 2013);

"... Compliance audits are aimed at checking the compliance of the relevant transactions with the compliance requirements set forth in legislation and making recommendations in order to improve the functionality of the internal control system" (National Audit Office of Estonia, 2014);

"... The objective of a compliance audit is to examine whether legislation, lower-level regulations and guidelines issued by authorities have been complied with in an area that falls within the National Audit Office's mandate. Compliance audit also strives to determine whether activities have been arranged in accordance with the budget, the principles of good administration, policies (objectives) and financial or agreement conditions" (National Audit Office of Finland, 2016);

"...Compliance audit shall mean the review of the financial management and control systems, including internal audit, and managerial decisions relating to the organisation, planning, management, reporting and control of budgetary and other public resources and activities within the audited organisation in respect of its adherence to requirements set out in statutory instruments, internal instruments and agreements" (Bulgarian National Audit Office, 2017);

"... The aim of a regulatory audit is to obtain assurance as to whether: transactions and operations of the audited entity comply with the requirements of laws and regulations; the design and application of the laws and regulations ensure transparency of the system. The regulatory audit includes a review of compliance of transactions and operations of the audited entity to the requirements of laws and regulations, as well as to the planned results" (State Audit Office of Latvia, 2015);

"... In its audit of regularity and compliance the Bundesrechnungshof examines whether the laws, the budget and pertinent regulations, provisions, and rules have been observed" (Bundesrechnungshof, 2016).

So, except for the direct correspondence of objective problems to the requirements of statutory instruments in force, budget and contractual terms, some SAIs also concentrate on a more detailed study in compliance auditing management decisions and transparency of the existing system.

The analysis of the terminology used shows that the concept of "regularity audit" is virtually put in the "compliance audit" because it includes the definition of 
statutory compliance in the executing some operations, programs, etc. Regularity audit had earlier spread in the practice of the SAIs overseas, such as Hungary, India, Netherlands, Pakistan, Slovenia, Tanzania, Uganda and so on. Thus, regularity audit is a constituent of compliance audit and one of its tasks, resulting in inappropriate singling out the regularity audit as the separate form of public audit.

When new 3rd level ISSAI standards were adopted in 2013, in particular, ISSAI 400 "Fundamental Principles of Compliance Auditing”, in October 28-29, 2014, under the National Audit Office of Lithuania guidance in Vilnius (Lithuania) the training seminar on "Compliance Audit: Use of the Compliance Audit Guidelines (ISSAI 400 and 4000-4999) and Best Practice" was held. The seminar took place as a part of EUROSAI operational plans "Professionals Standards" and "Knowledge Sharing" involving the representatives of the INTOSAI SubCommittee on Compliance Audit aimed at discussing the key problems of ISSAI standards implementation in compliance auditing and finding their solutions.

Key features of public audit, which were provided by the workshop participants having a positive experience of implementing the public compliance auditing in their SAIs' activities, are as follows.

Under the regulatory compliance, the regulatory environment is supposed, to which public authorities and government officials must correspond in order to obtain public confidence.

Two compliance concepts are proposed to use:

(1) regularity - activities, transactions and data reflected in the financial reports of the audited entity comply with the legislation, statutory instruments and instructional materials issued in accordance with the requirements of legislation in force and authorized in a proper manner, other agreements including budget laws;

(2) propriety - includes general concepts both of due financial management in the public sector and company officials' behaviour.

The concept of propriety is more difficult to apply since it is based only on the auditor's judgment and bears the mark of subjectivity. For example, the definition of the relevant correctness criteria is a challenging task as these criteria may be less formal and require considering public expectations regarding the public officials' actions and behaviour.

In foreign countries, when applying the propriety concept it is often assumed that the public auditor must find not only what is written in the laws, regulations and official records of Parliament and government. Special attention is paid to the ethical issues, despite the fact that legal is not always moral and vice versa. Simultaneous compliance with the requirements of legitimacy and ethics is the basis for good governance.

Some countries conduct a compliance auditing (CA) on a regular basis, including it in work agendas for a year, others - 1-2 times a year on the basis of an important study object. Thus, the Bulgarian National Audit Office conducts dozens of CAs over the year exploring the financial management of individual government agencies and organizations, agencies, offices, departments, etc. At the same time, the National Audit Office of Finland performs two to four public compliance audits annually, choosing the significant subjects for study such as: funding for organizations and foundations to promote health and social welfare; central government transfers to local government for expenditure on basic social assistance; the payment of state matching funds to universities; energy subsidies; compensations; budget procedures, etc.

This difference in approaches affects the SAI's planning process; however, it should not significantly impact the procedure of a compliance auditing.

Another feature of the compliance auditing organization and performance is the combination with other forms of public audit - financial auditing (FA) and performance auditing (PA). Depending on the goals and tasks, different approaches to conduct compliance auditing are identified. Sometimes CA is an independent task, but often it can act as a separate task when conducting comprehensive public auditing. In such cases, the combination of tasks and strategies of various public audits organizing and conducting is also of particular interest. Various combinations of both financial auditing and compliance auditing tasks described by the seminar attendees are summarized in Table 1.

Table 1

Combinations of the public financial auditing and the public compliance auditing

\begin{tabular}{|c|c|c|c|}
\hline \multirow{2}{*}{ Parameters } & \multicolumn{3}{|c|}{ Options for combinations of the Financial Auditing and the Compliance Auditing } \\
\hline & full integration & loose combination & segregation \\
\hline Basic methodology & $\begin{array}{l}\text { same basic methodology - } \\
\text { an assertion based, test of internal } \\
\text { control, substantive testing }\end{array}$ & $\begin{array}{l}\text { FA based on ISSAI } 1000 \text {, } \\
\text { different methodology for CA }\end{array}$ & $\begin{array}{l}\text { FA based on ISSAI } 1000, \\
\text { CA based on specific subject matters } \\
\text { according to ISSAI } 4000 \text { series }\end{array}$ \\
\hline Planning and execution & full integration & loose integration & no integration \\
\hline Assurance & $\begin{array}{l}\text { positive assurance on the financial } \\
\text { statement and positive assurance } \\
\text { on CA }\end{array}$ & $\begin{array}{l}\text { positive assurance on the financial } \\
\text { statement, and negative assurance } \\
\text { on CA }\end{array}$ & $\begin{array}{l}\text { positive assurance on the financial } \\
\text { statement, positive assurance on each } \\
\text { individual CA }\end{array}$ \\
\hline $\begin{array}{l}\text { Countries that apply } \\
\text { the approach }\end{array}$ & Estonia & Latvia, Canada, USA & Norway \\
\hline
\end{tabular}


The combination of the compliance auditing with the performance auditing does not cause, in practice, special problems, because these two forms of the audit have nearly always associated issues.

It should be noted that in different forms of public audit, critical attention is paid to the relationship between public auditors and the audited entity. Establishing a mutual understanding contributes to the audit's quality and efficiency, as well as to the increase in public confidence towards the audit results stated in the reports.

Thus, the report on the results of compliance auditing is important because it has to send the fullest, verifiable and understandable information to interested users. There are differences in the reports' presentation based on the CA results, as well as in the language of their submission. In effect, there are two basic report formats: (1) the extended presentation of results with appropriate criteria-based evaluation resulting in its long form;

(2) an auditor's regular, often short, statement.

In many instances, SAIs publish the reports in both formats on their public resources. At this, the extended (long) report is generally presented in a state language, and the short one - in English.

In light of this, the suggestions of the National Audit Office of Estonia regarding the preparation of a qualitative report on the compliance auditing results are useful. So, to shorten the report preparation time, a template can be developed. In order for a public auditor's idea about the subject for an audit represented in summary to be clear, it must be highlighted what they were doing, for what purpose and what is found. The quality of data reporting that may be of interest to both Parliament and the public also plays an important role. To improve the report's informative value, all the important information about the deviations or recommendations should be structured and represented by tables or graphs, etc.

To enhance the clarity of reports and conclusions based on the compliance auditing results and to improve their effectiveness, the Supreme Audit Office of Poland recommends: to write the report in simple language that conveys the meaning of work conducted clearly and accurately, makes it interesting for users; strongly emphasize the importance of the recommendations given; be fair and impartial while passing an opinion; describe only important issues which are of significance for the conclusion; provide convincing and well-founded conclusions which must contain specific and realistic recommendations to implement (Sulkowska, 2014).

In addition, the seminar covered the specific SAIs case studies of Estonia, Finland, Hungary, Latvia, Lithuania, and Turkey, the findings of which have enriched the experience of all parties concerned. Thus, the best experience of SAIs in different countries regarding public compliance auditing was the basis for the ISSAI standards.

\section{Analysis of the ISSAI standards key requirements as to the public compliance auditing}

Compliance auditing favours transparency by providing reliable information about how public resource management is effected and about the observance of citizens' rights according to legislative requirements. It also contributes to responsibility for all the deviations and irregularities found in the government bodies activities, because in accordance with any findings the corrective measures are taken and those found responsible are made accountable. Good governance support takes place by identifying weaknesses and deviations from laws, rules, and regulations with propriety assessment in cases when laws and other statutory instruments are not enough adequate. In addition, CA reduces the risk of fraud and corruption that hamper transparency, accountability, and good governance.

Taking into account the latest changes, the ISSAI standards on the $3 \mathrm{rd}$ and 4 th levels contain requirements for compliance auditing: ISSAI 100 "Fundamental Principles of Public-Sector Auditing", ISSAI 400 "Fundamental Principles of Compliance Auditing", and ISSAI 4000 "Compliance Audit Standard".

Key requirements for CA are contained in ISSAI 400, which is based on ISSAI 100 and concretizes it, in particular, regarding the purpose and justification for the ISSAI standards use while conducting the compliance audit, CA fundamentals and different ways of its implementation, as well as elements and principles.

To conclude, ISSAI 300 gives the following CA definition:

"Compliance auditing is the independent assessment of whether a given subject matter is in compliance with applicable authorities identified as criteria. Compliance audits are carried out by assessing whether activities, financial transactions and information comply, in all material respects, with the authorities which govern the audited entity" (ISSAI 300, 2013).

The ISSAI standards provide a wide range of principles, standards, and guidelines to study the subject of the audit, applying certain methods and report formats. CA guidelines (ISSAI 4000-4999), as noted above, are developed in line with the best practices, which allows them to be recommended to other SAIs. At the same time, there can be conditions which make impossible their use either in whole or in part. For example, this may occur in case of lack of basic administrative arrangements or if the legislation does not specify certain prerequisites for the CA conduct. In such cases, SAIs are free to determine the manner and the extent of the relevant ISSAI standards application.

The purpose of CA is to assess how the activities of public sector subjects correspond to their powers, which also includes reporting as to the audited item's 
compliance level to the criteria specified. As noted above, CA can be associated with the definitions of regularity or propriety. Despite the fact that the main focus of CA is the definition of regularity, propriety, however, is of great importance in the context of public expectations as to financial management and the officials' activities in the public sector.

The direction of establishing the propriety by public auditors as a result of CA depends on the SAIs' powers. For example, in countries such as Belgium, France, and Italy, SAI is authorized for jurisdictional function. For these SAIs, CA performance will have the features that make additional requirements for auditors, in particular, the judicial role. As SAIs with jurisdictional function are eligible to hold court and their decisions have greater consequences, the additional requirements regarding the auditing organization are laid down to them. As a result of the CA, such SAIs can exercise judgments and apply sanctions to the persons responsible for the public funds and other assets management. So, it may be suggested about the need to bring to responsibility for the lost revenues, illegal or inefficient public funds use, to impose sanctions and so on. Some SAIs are required to pass the facts elicited to the judicial branch. Such powers, of course, will affect the public compliance auditing preparation and conduct, including strategy and plan development, final documents regulation, etc.

In addition, some SAIs, depending on their powers, can hold CA in such cases:

(1) to determine the legality of certain activities, when there are suspicions of fraud and corruption;

(2) to determine the number of persons who can be brought to responsibility, in particular, a criminal one, due to the discrepancy in their activities with the current legislative requirements;

(3) to assess the reliability and completeness of data offered to the Parliament by the government, etc.

The authority designated will influence the determining objectives and strategies, planning and auditing procedures.

General requirements to a public compliance auditing conduct are set out in the ISSAI 4000 and relate to the following: objectivity and ethics, audit risk, the risk of fraud, selection of areas significant for the intended user(s), professional judgment and scepticism, quality control, documentation and communication.

An important feature of the public compliance auditing is that according to the results, the auditor may express a reasonable or limited assurance. To formulate a reasonable assurance, the public auditors should perform advanced procedures with the aim to collect more evidence.

The main stages of public compliance auditing are stated in the algorithm of conducting public compliance auditing (Figure 1), which was developed based on the ISSAI's essence analysis.

\section{Prospects for the public compliance auditing implementation in the Ukrainian practice}

First of all, it should be noted that the public compliance auditing implementation is directly related to the development of public audit in Ukraine. In this context, an important factor is that the system of public finance control is in the process of harmonization with international standards and is directly dependent on the new institutions' formation, supporting the transition toward a market economy.

The remoteness of global processes in the area of control, which objectively existed prior to Ukraine's independence proclamation in 1991, has not allowed to adequately perceive the leading foreign experts' achievements and to benefit from the experience of other countries in this area. The consequence was that the legislative practice outstripped Ukrainian theoretical developments in the field of control and audit.

Research activities of the last decade are based on the usual for Ukraine practice of strong government control, exaggerating its role and capabilities in providing independent and public control (Bardash, 2010; Sukhareva and Fedchenko, 2013; Mnichatall, 2015).

This is also evidenced by both the legal regulations in this area and the results of the Accounting Chamber' control capacity analysis, as well as its comparison with the government supervisory authorities, which have considerable advantages in terms of staff number, the territorial coverage of the Ukrainian regions and the number of the control activities (Khmelkov, 2016).

It should be noted that in the Ukrainian publications, the compliance auditing, unlike the financial auditing and the performance auditing, remains underexplored, which causes its character misunderstanding and sometimes - a mix of tasks of public audit's different forms. For example, public compliance auditing is the same as the public financial auditing (Dykan, 2011).

The analysis of both scientific publications (Bardash and Osadcha, 2012; Mnichatall, 2015; Nevidomyi, 2016; Pikhotskiy, 2016) and the current situation in Ukraine in terms of public finance control system transformation enabled to define the main groups of problems (Table 2).

The development of public audit institution will contribute to the development of its individual forms, in particular, the public compliance auditing. To accelerate the ISSAI standards implementation in the Accounting Chamber's practice, it is necessary to use the best practices of the SAIs that have experience in this field. Such an approach will also allow avoiding common errors and ensuring the compliance auditing performance. It should be noted that usually, the elements of compliance auditing are present in almost every control and expert-analytical event of the Accounting Chamber of Ukraine, but separately, as a form of public auditing, the compliance auditing in 


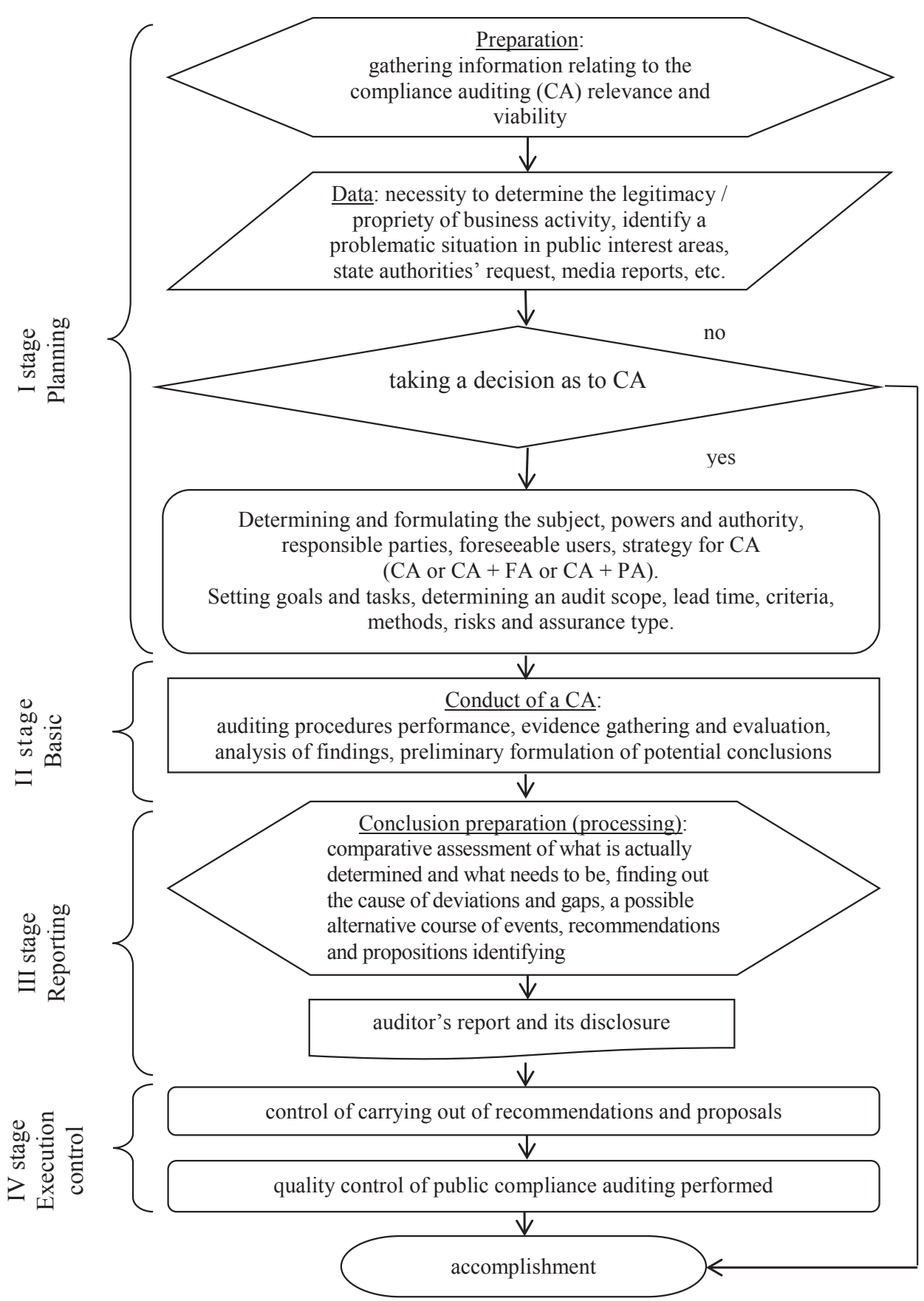

Figure 1. The algorithm of public compliance auditing conduct under the ISSAI requirements

Ukraine has still not been considered. For clarity, let us analyse some of the Accounting Chamber of Ukraine's recent reports on the results of audits and other control activities that are published on the official Chamber's website (ACU, 2017).

Thus, the analysis of various control measures key parameters proves that almost every one of them contains the compliance auditing elements. There is a clear connection between the objective, auditing criteria and methodological techniques of data collection, in which there are elements of regularity and propriety definitions. The elements of compliance auditing appear when combining with the financial audit and the performance audit (as provided for in the ISSAI standards). Table 3 presents some reports extracts to confirm this thesis.

The report analysis presented by the Accounting Chamber of Ukraine proves that in fact, the Chamber carries out public compliance audit but it does not call them so. For example, while describing the audit criteria (control measure) the parameter "legality" is emphasized. Information on this parameter is shown in Table 3. 
Vol. 4, No. 5, 2018

Table 2

Key problems in public audit in Ukraine at the present stage

\begin{tabular}{|c|l|}
\hline Problems nature & \multicolumn{1}{c|}{ Problems essence } \\
\hline Conceptual problems & $\begin{array}{l}\text { the lack of conventional concept used; } \\
\text { the need to formulate the public audit principles in order to take them as a basis for public auditing development; } \\
\text { the need to develop a sound scientific classification of the public audit's types and forms; } \\
\text { the need to define roles and tasks, subject and classification of public audited items; } \\
\text { the need to develop criteria of the efficiency of the public audit with regard to its essence and functions }\end{array}$ \\
\hline $\begin{array}{l}\text { Methodological } \\
\text { problems }\end{array}$ & $\begin{array}{l}\text { the constrained use of specific advanced methods and procedures of public audit, as well as the methods of audit } \\
\text { governance; } \\
\text { the lack of sound approaches to defining the importance and risks in public audit; } \\
\text { the need to develop and implement an effective system of public audit quality control (both internal and external } \\
\text { quality control) }\end{array}$ \\
\hline $\begin{array}{l}\text { Organizational and } \\
\text { legal problems } \\
\text { the lack of theory, which should be the basis for the public finance control transformation and development; } \\
\text { auditing of local budgets and other public resources is not included in the Accounting Chamber's powers; } \\
\text { the Accounting Chamber's organizational structure underdevelopment; } \\
\text { the lack of development of both internal and external public audit coordination model; } \\
\text { underestimation of the engaging independent auditors to conduct public audits }\end{array}$ \\
\hline
\end{tabular}

Table 3

Key parameters of an audit in the Accounting Chamber of Ukraine's reports

\begin{tabular}{|c|c|c|c|}
\hline asure & Goal & Legitimacy criteria & Data-collection methods \\
\hline $\begin{array}{l}\text { Audit of the tasks and actions } \\
\text { implementation designed by } \\
\text { the National target program } \\
\text { "Drinking Water in Ukraine" } \\
\text { for 2011-2020 }\end{array}$ & $\begin{array}{l}\text { establishing the real situation as to } \\
\text { planning and use of funds of the State } \\
\text { budget of Ukraine, prescribed in } \\
2012-2015 \text { to accomplish tasks of the } \\
\text { National target program "Drinking } \\
\text { Water in Ukraine" for 2011-2020 }\end{array}$ & $\begin{array}{l}\text { correspondence of management } \\
\text { decisions, departmental } \\
\text { normative legal acts and } \\
\text { executive directives of the } \\
\text { audited items with the applicable } \\
\text { law principles }\end{array}$ & $\begin{array}{l}\text { analysis of statutory instruments, } \\
\text { policy acts and executive } \\
\text { directives related to the audited } \\
\text { subject }\end{array}$ \\
\hline $\begin{array}{l}\text { Analysis of the executing } \\
\text { powers by the executive } \\
\text { bodies as to the taxpayers' } \\
\text { registration completeness }\end{array}$ & $\begin{array}{l}\text { determining the actual } \\
\text { implementing by the executive } \\
\text { authorities their powers regarding } \\
\text { the taxpayers' registration } \\
\text { completeness - legal entities and } \\
\text { their separate subdivisions, and } \\
\text { individuals }\end{array}$ & $\begin{array}{l}\text { compliance of managerial } \\
\text { decisions and regulatory } \\
\text { documents adopted by executive } \\
\text { bodies to the requirements of } \\
\text { current legislation in terms of } \\
\text { taxpayers registration }\end{array}$ & $\begin{array}{l}\text { collection and processing of } \\
\text { normative-legal acts, administrative, } \\
\text { regulatory and other documents } \\
\text { regulating the taxpayers' registration } \\
\text { procedure, as well as ensuring } \\
\text { control over the taxpayers' } \\
\text { registration completeness }\end{array}$ \\
\hline $\begin{array}{l}\text { Audit of the efficient use of } \\
\text { state budget funds allocated } \\
\text { to the Ministry of Health of } \\
\text { Ukraine to give the Ukrainians } \\
\text { medical treatment abroad }\end{array}$ & $\begin{array}{l}\text { assessing the legality, timeliness, } \\
\text { and completeness of management } \\
\text { decision-making }\end{array}$ & $\begin{array}{l}\text { conformity of managerial } \\
\text { decisions, executive directives } \\
\text { of audited items regarding the } \\
\text { planning and use of budget funds } \\
\text { with the current legislation }\end{array}$ & $\begin{array}{l}\text { analysis of normative and legal, } \\
\text { administrative, executive acts } \\
\text { and documents regulating } \\
\text { organizational and financial } \\
\text { support of medical treatment for } \\
\text { the Ukrainians abroad }\end{array}$ \\
\hline $\begin{array}{l}\text { Analysis of using the } \\
\text { International Coordinated } \\
\text { Audit of the Chornobyl } \\
\text { Shelter Fund ("Ukryttia" } \\
\text { Chornobyl Fund) } \\
\text { recommendations }\end{array}$ & $\begin{array}{l}\text { determining the actual situation } \\
\text { as to implementing the projects } \\
\text { (programs) associated with the } \\
\text { taking ChNPP out of service and } \\
\text { with the transforming the Shelter } \\
\text { into an environmentally safe system; } \\
\text { evaluating the legal and organizational } \\
\text { support in executing the International } \\
\text { Coordinated Audit of the Chernobyl } \\
\text { Shelter Fund's recommendations }\end{array}$ & $\begin{array}{l}\text { completeness, timeliness, and } \\
\text { consistency of implementing } \\
\text { the recommendations, the } \\
\text { extent to which the results } \\
\text { obtained thanks to executing the } \\
\text { recommendations correspond to } \\
\text { the target }\end{array}$ & $\begin{array}{l}\text { monitoring of legal, regulatory } \\
\text { and other documents regulating } \\
\text { the use of international technical } \\
\text { assistance and transfers from the } \\
\text { State Budget of Ukraine aimed at } \\
\text { implementing the measures for } \\
\text { the taking ChNPP out of service } \\
\text { and for transforming the Shelter } \\
\text { into an environmentally safe } \\
\text { system }\end{array}$ \\
\hline $\begin{array}{l}\text { Audit of financial and } \\
\text { economic activities of the } \\
\text { State territorial-sectoral } \\
\text { association "South-West } \\
\text { railway" }\end{array}$ & $\begin{array}{l}\text { evaluating the compliance with } \\
\text { laws and decisions of authorized } \\
\text { body of South-West railway's } \\
\text { property management, as well as of } \\
\text { the regulatory body of the railway } \\
\text { transport }\end{array}$ & $\begin{array}{l}\text { compliance of managerial } \\
\text { decisions, regulatory and } \\
\text { departmental normative legal } \\
\text { acts of the audited items to the } \\
\text { active legislation provisions, } \\
\text { compliance with the legislation } \\
\text { requirements, acts and decisions }\end{array}$ & $\begin{array}{l}\text { analysis of normative-legal, } \\
\text { administrative acts related to the } \\
\text { subject and the objects of the } \\
\text { audit }\end{array}$ \\
\hline
\end{tabular}


When comparing the information presented with the international episodes, it is possible to draw a conclusion about the full integration of the public compliance auditing with the public financial auditing in the Accounting Chamber of Ukraine's practice (Table 1). In addition, there are also elements of assessing the accuracy when performing compliance auditing (for example, determining the compliance of managerial decisions to the criteria specified).

Thus, public compliance auditing is actually conducted by the Accounting Chamber; however, it requires to be allocated as a separate form of the public audit as required by the ISSAI standards. As noted above, the latest version of the Law of Ukraine "On the Accounting Chamber" does not contain the concepts of compliance auditing. Virtually the only Ukrainian regulation, where compliance auditing is mentioned separately from other forms, is Internal Audit Standards, developed by the Ministry of Finance of Ukraine with the aim to use them in the ministries and other central executive bodies, their territorial bodies and budget institutions, etc. (MFU, 2011).

Thus, Section III, "Standards of internal audit activities", Chapter 1, "Directions of an internal audit", item 1.1 specify: "The scope of internal audit covers the following activities: ...assessment of the institution's activity in terms of compliance with the legislation, plans, procedures, contracts regarding the asset conservation, information and state property management (compliance auditing" (MFU, 2011). The Internal Audit Standards do not specify the compliance auditing procedures as well.

Regulatory documents of the Accounting Chamber do not stipulate the public compliance auditing as a separate form of the public audit. Thus, the methodology of the CA is not designed, which disallows for full use of this form of the public auditing.

\section{Proposals to ensure public compliance auditing implementation in Ukraine}

This study allows formulating the recommendations for further public compliance auditing implementation in Ukraine, which are as follows.

(1) Conceptual framework (definitions) used in public audit requires to be developed and specified. Further investigation of public audit theory and methodology, in particular, the public compliance audit, as well as the best practices studying will achieve the conventionality of concepts applied that should be the basis for the relevant normative-legal acts. The terminology solidarity is essential to improve the coordination of internal and external public audit subsystems, as well as their interaction with other stakeholders.

(2) Supplementing the list of the Accounting Chamber of Ukraine's control measures with the public compliance auditing would be the next step. As it has been proven in the study, the public compliance auditing is a distinct form of the public audit with its own specifics of the organization and conduct. In addition, the specified adjustment will allow bringing the actual legislation into compliance with the ISSAI standards.

(3) To fully include public compliance audits to the Supreme Audit Institution's work requires defining the concept of compliance auditing. According to the current practice, compliance auditing is conducted on an ongoing basis including the plans for the year or based on choosing the essential subject for study (multiple audits). In our opinion, it is advisable to flexibly combine these two approaches in a flexible manner. Taking into account the Accounting Chamber of Ukraine's current practice, it seems rational to define a list of public audit items, which requires a regulatory basis for periodic compliance auditing (for example, separate ministries and departments). Along with this, resources to carry out compliance auditing on individual topical issues must be included into the Chamber's annual work.

It is worthy of note that while planning the Accounting Chamber of Ukraine's activities the communication with The State Audit Service of Ukraine (the main monitoring body of the government) regarding the internal compliance auditing execution plan will play a critical part. In this case, it is possible to avoid undesirable duplication of internal and external audit functions.

(4) When the appropriate amendments in the law are introduced the developing separate Standard (or Methodical recommendations) on carrying out the public compliance audit by the Accounting Chamber of Ukraine will be a logical step. The ISSAI standards requirements must be the basis for this internal regulatory document. It is also advisable to use the best practices of other Supreme Audit Institutions and to attract the scientists making investigations in this area.

(5) Full implementation of the public compliance auditing is only possible with trained professionals. On that basis, training and professional development of public auditors as to the public compliance audits methodology and organization are extremely important.

(6) Sharing experience with Supreme Audit Institutions of foreign countries concerning the organization and conduct of public compliance audits in this context will help to implement compliance auditing.

(7) The allocation of internal public compliance auditing in The State Audit Service of Ukraine activities will allow normalizing the control subsystems of both external and internal public audits that will ensure their effectiveness and efficiency. Creating a database for sharing results and coordination in the planning and conduct of internal and external public compliance audits should be an important step in this direction. Modern technologies allow ensuring the proper functioning of such a database in compliance with the limited access requirements and information confidentiality. 


\section{Future research opportunities}

In sum, we note that the public compliance auditing is a promising direction of research in the public finances control area. At the same time, the results presented in the study can be the basis for further theoretical and practical developments, and taking the recommendations proposed into account will speed up the process of the ISSAI standards implementation, improve the public audits quality and efficiency to ensure public confidence towards the Supreme Audit Institution in Ukraine.

\section{Discussion and conclusion}

The purpose of this study was to determine the prospects of implementing the public compliance audit in Ukraine according to the ISSAI standards requirements. For this purpose, the prerequisites for the development of public compliance auditing as one of the forms of the public audit were investigated based on the best international practice in this area.

As a result, the following conclusions were drawn.

First, the compliance auditing is known since ancient times and is widely used in the SAIs' practice, but it sometimes has other names (regulatory, regularity). However, its main essential characteristics are preserved (essence, goal, realization conditions, presentation of results, etc.). In view of this, separating the regularity auditing as a certain form of public audit seems to be inappropriate.

Second, the longstanding applying the public audit by different SAIs confirmed the appropriateness of its carrying out as a separate form of the public audit that has highlighted the need to develop appropriate methodological support. The latter was confirmed by the professional community and implemented in the form of the 3rd and 4th level ISSAI standards. The standards were adopted by the INTOSAI Congress in December 2016 and now they require to be implemented by all INTOSAI-members.

Third, Ukraine goes through the transformation process of the public finance control system and is an active international institutions participant, which implies the ISSAI standards implementation. Dealing with theoretical, methodological, and organizational and legal problems will speed up reforms in the sphere of external independent control. With the development of the public audit institution, the development of individual forms, in particular, the public compliance auditing, will take place.

Fourth, the analysis of reports based on the Accounting Chamber of Ukraine's performance has proved that almost every control measure produced by the Chamber contains the compliance auditing elements. In this case, the proper legal basis for the CA as a separate form of the public audit has not yet been established and the relevant methodological developments are lacking.

Fifth, to accelerate the ISSAI standards implementation in the Accounting Chamber's practical activity, the specific recommendations are proposed, the implementation of which will contribute to reforming the control system in accordance with the international standards requirements and national needs for the improvement of public administration in Ukraine.

\section{References:}

Accounting Chamber of Ukraine (ACU) (2016). Annual Reports of the Accounting Chamber. Retrieved from: http://www.ac-rada.gov.ua/control/main/en/publish/category/32832 (accessed 23 May 2017).

Arens, A. A., Elder, R. J., Beasley, M. S. (2012). Auditing and assurance services: an integrated approach, 14th ed., Pearson.

Bardash, S., Osadcha, T. (2012). State financial control in Ukraine: current conditions, problems and ways of improvement, in European Science and Technology proceeding of the II international research and practice conference in Wiesbaden, Germany, 9-10 May, 2012, Vol. I, Publishing office "Bildungszentrum Rodnik e. V.,' Wiesbaden.

Bardash, S. V. (2010). Economic control in Ukraine: systematic approach, Kyiv National University of Trade and Economics, Kyiv.

Barzelay, M. (1997). Central Audit Institutions and Performance Auditing: A comparative Analysis of Organisational Strategies in the OECD. Governance, 10(3), 235-260.

Bowerman, M., Humphrey, C. and Owen, D. (2003). Struggling for supremacy: the case of UK public audit institutions, Critical Perspectives on Accounting, 14(1-2), 1-22.

Bulgarian National Audit Office (2017). Types of audits. Retrieved from: http://www.bulnao.government.bg/en/ articles/types-of-audits-923 (accessed 4 June 2017)

Bundes Rechnungshof (2016). Regularity, Compliance and Performance Auditing. Retrieved from: http://www.bundesrechnungshof.de/en/bundesrechnungshof/pruefungsverfahren/pruefungsmassstaebe-sindordnungsmaessigkeit-und-wirtschaftlichkeit (accessed 3 June 2017)

Chartered Institute of Public Finance and Accountancy (CIPFA) (2014). International framework: good governance in the public sector. Retrieved from: http://www.cipfa.org/policy-and-guidance/standards/ international-framework-good-governance-in-the-public-sector (accessed 3 June 2017)

Committee of Sponsoring Organizations of the Treadway Commission (COSO) (2013). The 2013 COSO Framework \& SOX Compliance: One Approach to an Effective Transition. Retrieved from: https://www.coso.org/ Pages/guidance.aspx (accessed 4 June 2017) 
Dye, K. M., Stapenhurst, R. (1998). Pillars of Integrity: the Importance of Supreme Audit Institutions in Curbing Corruption. The Economic Development Institute of the World Bank, Washington.

Dykan, L. V. (2011). State Audit, Knowledge, Kyiv.

Funnell, W. (1994). Independence and the State Auditor in Britain: A constitutional keystone or a case of reified imagery? Abacus, 30(2), 175-194.

Gomes, M. B. (2001). Performance Audit Argument: a Public Management Policy Analysis about Supreme Audit Institutions Role. XV Concurso de Ensayos del CLAD "Control y Evaluacion del Desempeno Gubernamental". Caracas. Hood, C. (1995). The 'New Public Management' in the 1980s: variations on a theme. Accounting, Organizations and Society, 20(2-3), 93-109.

Hua-Wei, H. (2009). Sarbanes-Oxley section 404 compliance: Recent changes in US-traded foreign firms' internal control reporting. Managerial Auditing Journal, 24(6), 584-598.

International Organization of Supreme Audit Institutions (INTOSAI) (2016). The Abu Dhabi Declaration. Retrieved from: http://www.intosai.org/fileadmin/downloads/downloads/5_events/congresses/EN_AbuDhabi Declaration.pdf (accessed 4 June 2017)

International Standards of Supreme Audit Institutions (ISSAI) (2016). ISSAI Framework. Retrieved from: http://www.issai.org/en_us/site-issai (accessed 4 June 2017)

Jones, R., Pendlebury, M. (2000). Public Sector Accounting, 5th ed., Prentice Hall, London.

Khmelkov, V. Andriy (2016). Audit Chamber of Ukraine as an agent within public finance control institute. Actual Problems of Economics, 5(179), 370-381.

Lenz, R., Hahn, U. (2015). A synthesis of empirical internal audit effectiveness literature pointing to new research opportunities. Managerial Auditing Journal, 30(1), 5-33.

Mayne, John (2006). Audit and evaluation in public management: challenges, reforms, and different roles. Canadian Journal of Program Evaluation, 21(1), 11-45.

Ministry of Finance of Ukraine (MFU) (2011). Internal Audit Standards. Retrieved from: http://zakon2.rada.gov.ua/ laws/show/z1219-11 (accessed 3 June 2017)

Mintzberg, H. (1980). Structure in 5's: A Synthesis of the Research on Organization Design. Management Science, 26(3), 322-341.

Mnich, E. V., Bardash, S. V., Nazarova, K. O. (2015). Financial audit: information and analytical support. Kyiv National University of Trade and Economics, Kyiv.

National Audit Office of Estonia (2014). Strategy of the National Audit Office 2014-2020. Retrieved from: http://www.riigikontroll.ee/ (accessed 3 June 2017)

National Audit Office of Finland (2016). Compliance audit. Retrieved from: https://www.vtv.fi/en/functions/ compliance_audit (accessed 3 June 2017)

National Audit Office of Lithuania (2014). Compliance Audit: Use of the Compliance Audit Guidelines (ISSAI 400 and 4000-4999) and Best Practice. Retrieved from: http://www.vkontrole.lt/CAseminar2014/ introduction.shtml (accessed 3 June 2017)

Nevidomyi, V. (2016). Strengthening the institutional capacity of the Accounting chamber of Ukraine as an independent state audit institution. The Journal Finance of Ukraine, 1, 116-125.

O’Regan, D. (2004). Auditor's Dictionary: Terms, Concepts, Processes, and Regulations, John Wiley \& Sons. Inc., New Jersey. Othman, R., Nath N., Mahzan, N. (2013). Public Sector Audit: A Century and Beyond- the Case of Malaysia. NZICA. Retrieved from: http://repository.um.edu.my/33955/1/Radiah\%20Othman\%20Public\%20Sector\%20 Audit\%20A\%20Century\%20and\%20Beyond\%20final.pdf (accessed 3 June 2017)

Pearson, D. (2014). Significant reforms in public sector audit - staying relevant in times of change and challenge. Journal of Accounting \& Organizational Change, 10(1), 150-161.

Pikhotskiy, V. F. (2016). The external state financial control over the activities of the executive power - an important factor in the protection of society. Business Inform, 2, 300-305.

Pollit, C. et al. (1999). Performance or Compliance? Performance Audit and Public Management in Five Countries. Oxford University Press, Oxford.

Reichborn-Kjennerud, K. (2013). Does performance auditing matter? The government administration's response to the performance auditing of the Norwegian Office of the Auditor General. Ph.D. thesis, University of Bergen, Norway.

Ruffner, M., Sevilla, J. (2004). Public sector modernisation: modernising accountability and control. OECD Journal on Budgeting, 4(2), 123-141.

State Audit Office (2015). Regulatory. Retrieved from: http://www.lrvk.gov.lv/en/results-of-audits/what-isaudit/types-audit/regulatory (accessed 3 June 2017)

Sukhareva, L. O., Fedchenko, T. V. (2013). State audit efficiency: systematic, organization, methodology. DonNUET, Donetsk.

Sułkowska, B. (2014). Compliance audit in NIK, paper presented at the EUROSAI Seminar "Compliance Audit: Use of the Compliance Audit Guidelines (ISSAI 400 and 4000-4999) and Best Practice”, 28-29 October 2014, Vilnius, Lithuania. Retrieved from: http://www.vkontrole.lt/CAseminar2014/materials/Wilno_prezbs.pdf (accessed 4 June 2017) 
Supreme Audit Institution of India (2013). Guidance Note on Types of Audit. Retrieved from: http://www.cag.gov.in/content/guidance-note-types-audit (accessed 3 June 2017)

The Institute of Internal Auditors (2012). Supplemental Guidance: The Role of Auditing in Public Sector Governance. Retrieved from: https://na.theiia.org/standards-guidance/Public\%20Documents/Public Sector Governance1_1_.pdf (accessed 02 June 2017)

United Nations (UN) (2011). Promoting the efficiency, accountability, effectiveness and transparency of public administration by strengthening supreme audit institutions. Retrieved from: https://documents-dds-ny.un.org/ doc/UNDOC/GEN/N11/471/36/PDF/N1147136.pdf?OpenElement (accessed 3 June 2017)

United Nations (UN) (2014). Promoting and fostering the efficiency, accountability, effectiveness and transparency of public administration by strengthening supreme audit institutions. Retrieved from: https://documents-dds-ny.un.org/ doc/UNDOC/GEN/N14/713/64/PDF/N1471364.pdf?OpenElement (accessed 4 June 2017)

United Nations (UN) (2015). Resolution adopted by the General Assembly on 25 September 2015. Transforming our world: the 2030 Agenda for Sustainable Development. Retrieved from: http://www.un.org/ru/documents/ ods.asp?m=A/RES/70/1 (accessed 3 June 2017)

Verkhovna Rada of Ukraine (VRU) (2015). Law of Ukraine On the Accounting Chamber. Retrieved from: http://www.ac-rada.gov.ua/doccatalog/document/16746311/Law_on_ACU.pdf (accessed 4 June 2017) 